\title{
THE POSSIBILITIES OF APPLICATION OF BACTERIAL LEACHING IN RETRIEVAL OF VALUABLE METALS FROM MINING WASTE
}

\author{
PETER FEČKO ${ }^{1}$, VOJTĚCH ZECHNER ${ }^{1}$, MICHAL GUZIUREK ${ }^{1}$, \\ BARBORA LYČKOVÁ ${ }^{2}$, EVA PERTILE ${ }^{2}$
}

\author{
${ }^{I} V \check{S} B-T U$ Ostrava, Institute of Clean Technologies for Extraction and Utilization of \\ Energy Resources, 17.listopadu Street 15, 70833 Ostrava, Czech Republic, \\ (vojtech.zechner@vsb.cz) \\ ${ }^{2} V \check{S} B-T U$ Ostrava, Institute of Environmental Engineering, 17.listopadu Street 15, \\ 70833 Ostrava, Czech Republic
}

\begin{abstract}
The paper deals with an application of bacterial leaching on two selected samples from old ecological loads situated in the Karlovy Vary Region. To be specific, they are heaps in Prebuz and Kraslice. Bacterial leaching was applied making use of Acidithiobacillus ferrooxidans bacteria and lasted 28 days. The results imply that the given method is suitable for the retrieval of valuable metals from waste and may help to deal with the issue of old heaps and dumps.
\end{abstract}

Keywords: Bacterial leaching, Acidithiobacillus ferrooxidans, mining waste heaps

\section{Introduction}

Mining of mineral resources and utilization of lithospheric sources always represent a substantial interference with the geological conditions in any territory. Mining endangers both the deposits and the natural environment. It causes decreases in the land resources, destruction of the vegetation cover, damage to the agricultural, forest and water management, destruction of settlements, worse environmental conditions and results in the anthropogenic georelief (BOSECKER, 1997; ZÁVADA and BOUCHAL, 2010). The major manifestations of the influence on the geomorphology by mining are anthropogenic movements caused by undermining, changes in the georelief (miming forms), influence of mining and waste on the landscape (removal of overburden, heaps, preparation tailings), pollution by preparation processes, collapse of quarry slopes and induced bursts (BROMBACHER et al., 1997; FEČKO et al., 2004). The remediated anthropogenic forms of landscape georelief may have various functions: protected natural phenomenon, non-toxic waste disposal site, agriculturally cultivated fields, recreation-sports facilities (playgrounds, swimming) or may be used as car parks, etc (LEDIN and PADERSEN, 1995). A collected evaluation of the environmental impacts of abandoned mine workings (predominantly for mining of building materials, ores, coal and uranium) in the CR showed that out of 2,000 mine workings in the CR $79 \%$ of them do not influence the environment in any way, more than $20 \%$ only marginally and with no long-term consequences. Mere $0.5 \%$ of mine workings are critical, with hazardous wastes, slag, contaminants, etc. It is surprising that only mining causes $1 / 3$ of the unfavorable influence on the natural environment. The prevailing part is of a different 
origin (unauthorized waste disposal sites, etc.). The consequences of mining are effaced by the auto-regulative powers of the nature with no human intervention only in a low extent. From this point of view, it is necessary to project the environmental settlement for using lithospheric sources into the gross domestic product calculation system.

As mentioned above, any extraction of mineral resources produces waste along with the major component. This waste is usually called mining waste. For example, it is waste rock, spoil, preparation tailings, etc. This waste is usually disposed of on heaps and dumps. However, it is often the case that the waste may be rich some elements, e.g. copper, gold. In the past, the elements remained unused because of economic intensity of their retrieval, but at present various methods tend to be applied to retrieve the valuable elements. Recently, one of the most effective methods has been bacterial leaching (TORMA, 1997; MARŠÁLEK, 1979; BOROVEC, 1989; CRUNDWELL et al., 2000; BOOM, 2001; KRAUS, 2006; FEČKO et al., 2008). The objective of the work is to identify what elements in which quantities are to be found in the samples from the above mentioned heaps related to extraction of copper and tin in the Karlovy Vary Region and how to extract them by means of bacterial leaching.

\section{Materials and methods}

\subsection{Characteristic of the locality Prebuz and Kraslice}

In the work two samples are described, namely from the locality of Prebuz and the locality of Kraslice. Fig. 1 shows the geological characteristic of the locality of Prebuz and Kraslice.

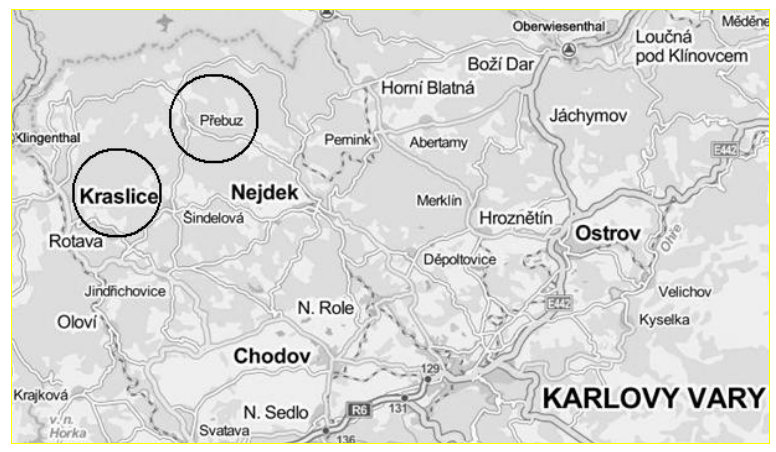

Fig. 1. Locality of Prebuz and Kraslice.

Prebuz is found in the district of Sokolov, in the Karlovy Vary Region. The mining locality is $1 \mathrm{~km}$ southwestwards from Prebuz at the foot of the Hartelsberg Hill. There is the most important tin district in the region. There are remnants of extensive mining and preparation activities from the $16^{\text {th }}-20^{\text {th }}$ century, e.g. shaft Otto, the main shaft with a shaft frame construction in good repair (technical monument), 45 rows of cave-ins - surface depressions, drift entrance, heaps of as-mined ore and waste rock, ore preparation plant frame, sludge ponds, tin placers and a lade. On the heaps there are granites in the Karlovy 
Vary pluton (earlier intruded complex), ore mineralization (Sn-greisens and several generation veins with ore mineralization of $\mathrm{Sn}, \mathrm{As}, \mathrm{W}, \mathrm{Fe}, \mathrm{Mn}, \mathrm{U}$, etc. Rare minerals can be found there (topaz, opal, secondary minerals of $\mathrm{As}, \mathrm{Cu}, \mathrm{Bi}$, U, etc.). It is a locality of supraregional importance to do research in the genesis of tin deposits of the greisens type. From the regional zoning point of view, it is the Bohemian Massif, crystalline complex and Prevariscan Paleozoic - saxothuringicum, Ore Mountains pluton. As for stratigraphy, they are igneous rocks of a Hercynian age. Figures 2 shows the character of the drawn samples from both the localities.
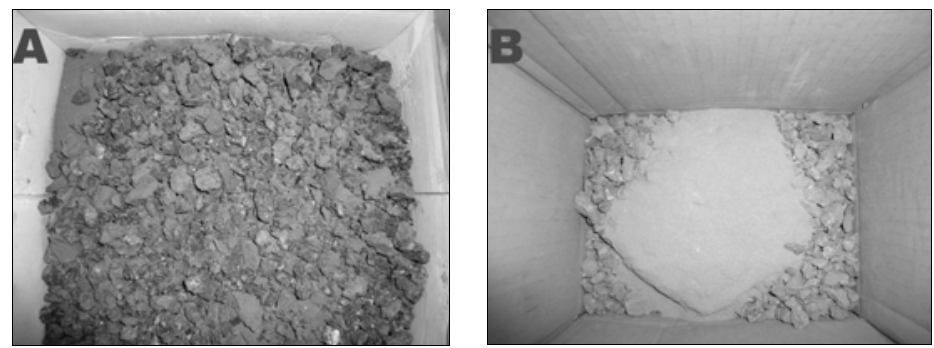

Fig. 2. Character of the sample after its drawing from the locality of Kraslice (A) and Prebuz (B).

\subsection{Mineralogical characteristics of the samples}

The mineralogical analyses were implemented using an X-ray analyzer in the laboratories of the Institute of Geological Engineering of VSB-TU Ostrava. The results imply that the Kraslice sample contains barite, cerussite, galena and quartz. The Prebuz sample contains muscovite and chlorite. Tables 1 and 2 state the percentages of the individual minerals in the tested samples.

Table 1. Mineralogical composition of the Kraslice sample.

\begin{tabular}{cc}
\hline Composition & Ratio (\%) \\
\hline Barite & $56.4 \pm 3.0$ \\
Cerussite & $2.4 \pm 1.1$ \\
Galena & $2.9 \pm 0.7$ \\
Quartz & $38.3 \pm 3.0$ \\
\hline
\end{tabular}

Table 2. Mineralogical composition of the Prebuz sample.

\begin{tabular}{cc}
\hline Composition & Ratio (\%) \\
\hline Chlorite 1lb-2 & $20.2 \pm 9.6$ \\
Muscovite_2M1 & $79.8 \pm 9.6$ \\
\hline
\end{tabular}

\subsection{Methodology of bacterial leaching}

Samples of $100 \%$ grain-size below $0.071 \mathrm{~mm}$ were prepared for bacterial leaching. A pure bacterial culture of Acidithiobacillus ferrooxidans was applied, coming from the Czech Collection of Microorganisms in Brno. A 5-litre bioreactor was used, into which $500 \mathrm{ml}$ of the bacterial culture were poured, followed by the tested samples and then 
Silverman medium 9K was added. Stirring in the bioreactor was ensured by means of aquarium pumps. The $\mathrm{pH}$ value of the solution was maintained at the range from 1.8 to 2.0 by means of $1 \mathrm{M}$ sulfuric acid during the overall experiment. Bacterial leaching was conducted at the laboratory temperature of $20^{\circ} \mathrm{C}$. The time of the experiment was 28 days and having finished the experiment, the samples were analyzed on an X-ray fluorescence analyzer.

\section{Results and discussion}

The evaluated test results are summarized in Tables 3 and 4. The stated results revealed that the highest recovery of $\mathrm{Cu}$ and $\mathrm{Pb}$, over $40 \%$, was obtained in the sample from Kraslice. From the presented results it is clear that the recovery with bacterial leaching depends on the primary concentration of an element in the waste rock. Of toxic elements, As exhibited variable behavior during leaching by Acidithiobacillus ferrooxidans; the ability of the element to be released is probably connected with the original concentration of the element in the waste rock (Fig. 3).

Table 3. Results of bacterial leaching of the Kraslice sample.

\begin{tabular}{cccc}
\hline Element & Prior to leaching (ppm) & Post leaching (ppm) & Recovery (\%) \\
\hline $\mathrm{Ca}$ & 3686 & 3572 & 3.1 \\
$\mathrm{Ti}$ & 116102 & 112663 & 2.7 \\
$\mathrm{Cr}$ & 3342 & 2944 & 11.9 \\
$\mathrm{Mn}$ & 1653 & 1085 & 34.4 \\
$\mathrm{Fe}$ & 7148 & 5383 & 24.7 \\
$\mathrm{Ba}$ & 414756 & 330033 & 20.4 \\
$\mathrm{Cu}$ & 5332 & 3040 & 43.0 \\
$\mathrm{Zn}$ & 1545 & 1338 & 13.4 \\
$\mathrm{As}$ & 2752 & 2456 & 10.8 \\
$\mathrm{~Pb}$ & 87988 & 48557 & 44.8 \\
$\mathrm{Sr}$ & 3099 & 2834 & 8.6 \\
$\mathrm{Sn}$ & 738 & 0.001 & 99.9 \\
$\mathrm{~V}$ & 18849 & 17908 & 5.0 \\
\hline
\end{tabular}

Table 4. Results of bacterial leaching of the Prebuz sample.

\begin{tabular}{cccc}
\hline Element & Prior to leaching (ppm) & Post leaching (ppm) & Recovery (\%) \\
\hline $\mathrm{Ca}$ & 17801 & 15164 & 14.8 \\
$\mathrm{Ti}$ & 9637 & 1774 & 81.6 \\
$\mathrm{Cr}$ & 680 & 0.001 & 99.9 \\
$\mathrm{Mn}$ & 1680 & 1300 & 22.6 \\
$\mathrm{Fe}$ & 234998 & 148019 & 37.0 \\
$\mathrm{Ba}$ & 7947 & 0.001 & 99.9 \\
$\mathrm{Cu}$ & 2447 & 0.001 & 99.9 \\
$\mathrm{Zn}$ & 3606 & 300 & 91.7 \\
$\mathrm{As}$ & 207 & 74 & 64.3 \\
$\mathrm{~Pb}$ & 1669 & 0.001 & 99.9 \\
$\mathrm{Sr}$ & 89 & 18 & 79.8 \\
$\mathrm{Sn}$ & 2988 & 0.001 & 99.9 \\
\hline
\end{tabular}

The dependence of the concentration of elements in the waste rock on the recovery with bacterial leaching shows a power trend with a high value of the correlation 
coefficient, i.e. $>0.98$. The activity of the bacteria may be affected by a relatively high concentration of toxic As in the environment of the bioreactor (STOLZ et al., 2006). In the case of the Prrebuz sample, better results were obtained; the concentration of metals in the waste rock was very low. The recovery was high, almost $100 \%$ in the majority of the elements, except for Fe and Mn.
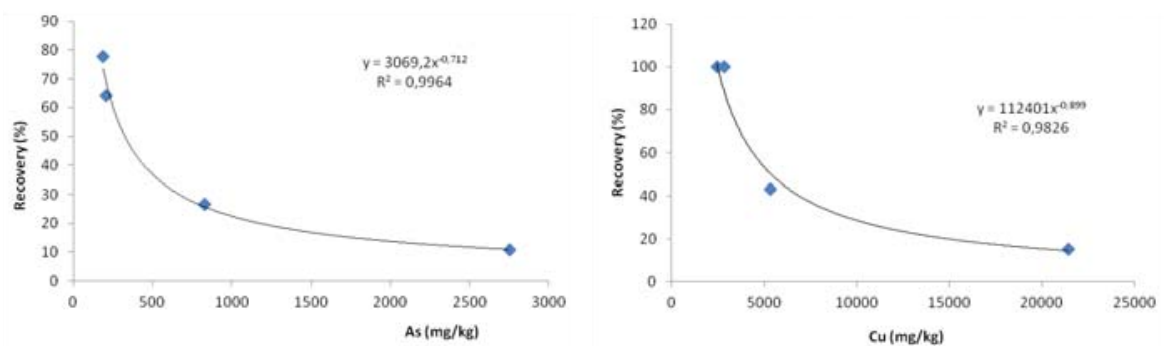

Fig. 3. Relationship between recovery of elements $(\mathrm{As}, \mathrm{Cu})$ during bacterial leaching and concentration of elements in waste rock.

\section{Conclusion}

The objective of the work was to test bacterial leaching using waste material samples from the localities of Kraslice and Prebuz applying the bacteria of Acidithiobacillus ferrooxidans. The obtained results imply that the given technology is suitable for the waste material drawn from the locality of Prebuz. In case of the slag material from the locality of Kraslice, it would be advisable to prolong the time of leaching. It is apparent from the above mentioned that applying an ecological technology it is possible to retrieve valuable metals from old heaps.

Acknowledgments: Article has been done in connection with project Institute of clean technologies for mining and utilization of raw materials for energy use, reg. no. CZ.1.05/2.1.00/03.0082 supported by Research and Development for Innovations Operational Programme financed by Structural Founds of Europe Union and from the means of state budget of the Czech Republic.

\section{References}

BOOM, M.: The mechanism of direct and indirect bacterial oxidation of sulfide minerals. Hydrometallurgy, 62, 2001, 67-70.

BOROVEC, Z.: Mikrobiologická oxidace sulfidických rud. Rudy, 37, 1989, 261-268.

BOSECKER, K.: Bioleaching: metal solubilization by microorganisms. FEMS Microbiol. Rev., 20, 1997, 591-604.

BROMBACHER, C., BACHOFEN, R., BRANDL, A.: Biohydrometallurgical processing of solids: a patent review. Appl. Microbiol. Biotechnol., 48, 1997, 577-587.

CRUNDWELL, F. K., HOLMES, P. R., FOWLER, T. A.: How do bacteria interact with minerals. J. S. Afr. Inst. Min. Metall., 100, 2000, 399-401.

FEČKO, P.; KUŠNIEROVÁ, M.; ČABLÍK, V.; PEČTOVÁ, I.: Environmentální biotechnologie, VŠB - TUO, Ostrava, 2004, 180 pp. 
FEČKO, P.; KUŠNIEROVÁ, M.; SOCHORKOVÁ, A.; PRAŠČÁKOVÁ, M.; OVČAŘ́, P.; MUCHA, N.; JANÁKOVÁ, I.: Biotechnólogie v úprave uhlia, VŠB - TUO, Ostrava, 2008, 156 pp.

KRAUS, S.: Metale pretioase-vol II. Matrix Rom, Bucuresti, Romania, 2006.

LEDIN, M., PEDERSEN, K.: The environmental impact of mine wastes - Role of microorganisms and their significance in treatment of mine wastes - survey. Göteborg University, Lundeberg Institute, 1995, 104 pp.

MARŠÁLEK, J.: Thiobacillus ferrooxidans a jeho kultivace v procesu biologického loužení rud. SNTL - Nakl. technické literatury, Praha, 1979, 143 pp.

STOLZ, J. F.; BASU P.; SANTINI, J. M.; OREMLAND, R. S.: Arsenic and Selenium in Microbial Metabolism. Ann. Rev. Microbiol., 60, 2006, 107-130.

TORMA, A. E. The role of Thiobacillus ferrooxidans in Hydrometallurgical Processes. In: GHOSE, T.K. AND FIECHTER, A. AND BLAKEBROUGH, N. (Eds.) Advances in Biochemical Engineering. Springer Berlin Heidelberg, Berlin, 1977, 1-37.

ZÁVADA, J., BOUCHAL, T.: Chemické metody zpracování nerostných surovin a odpadů, VŠB - TUO, Ostrava, 2010, 99 pp.

Presented at the 2nd International Conference "Biotechnology and Metals - 2011", September 22-23, 2011, Košice, Slovak Republic. 